\title{
The Impact of Legislator and Constituency Ideology on Voting on the Assault Weapons Ban
}

\author{
MARSHALL. H. MEDOFF* \\ CHRISTOPHER DENNIS \\ California State University at Long Beach \\ BENJAMIN G. BISHIN \\ University of California at Los Angeles
}

\begin{abstract}
Using variables that represent a legislator's entire legal constituency, previous research by social scientists has concluded that views of the legislator's constituency have little effect on how legislators vote. This question is reexamined by defining constituency as those voters most likely to vote for the legislator (i.e., members of the legislator's own political party and independents). Furthermore, instead of measuring constituency by either a demographic or vote-based measure, a survey measure of the ideological identification of voters (i.e., the voter's self-identification as liberal, moderate, or conservative) is introduced. It is found that the ideology of a senator's electoral constituency was an important factor on the recent U.S. Senate vote to ban 19 semi-automatic assault weapons. The findings have important implications for how social scientists conceptualize and measure constituency.
\end{abstract}

\section{INTRODUCTION}

One of the most important and widely researched topics of legislative behavior concerns the degree to which legislators vote in accordance with the views of their constituency as opposed to their own ideology (see, e.g., Goff \& Grier, 1993; Krehbiel, 1993). Thus far, the literature seems to suggest that in most circumstances, the leg-

* Direct all correspondence to: Marshall H. Medoff, Department of Economics, California State University, 1250 Bellflower Boulevard, Long Beach, CA 90840-4605.

Journal of Socio-Economics, Volume 24, No. 4, pp. 585-591

Copyright $\odot 1995$ JAI Press Inc.

All rights of reproduction in any form reserved.

ISSN: 1053-5357 
islator's own ideology is a much better predictor of their voting than the characteristics of their legal constituency (Bernstein, 1989; Krehbiel, 1993).

While the empirical literature has generally emphasized the importance of the legislator's ideology on voting, both conceptual and measurement problems may have led researchers to discount the importance of constituency. Democratic and Republican politicians have strong ideological differences. Voters frequently use political party affiliation as a low-cost information proxy for a candidate's position on a variety of issues. Since voters often use the political party affiliation of candidates as a basis for voting, it makes sense to conceptualize a legislator's constituency in partisan terms. Thus, we can think of a legislator's "electoral" constituency as being those voters most likely to support the legislator (Fenno, 1978; Goff \& Grier, 1993). As Krehbiel (1993, p. 24) notes, by using measures of the entire legal constituency, testing the relative importance of the electoral constituency and the legislator's ideology on voting is precluded.

The purpose of this article is to estimate the impact of the ideology of the legislator and his or her electoral constituency on voting. Specifically, we examined U.S. Senate voting on the Feinstein (D-California) Amendment to ban assault weapons. The Feinstein Amendment bans the future sale, possession, and manufacture of 19 semi-automatic assault weapons and copycat models (Congressional Quarterly Weekly Reports, 1993, p. 3228).

This was a particularly important vote to study for several reasons. First, the assault weapons ban was a highly visible issue. Thus, a senator's constituency was likely to be aware of the senator's vote. Second, since crime has been a prominent issue in political campaigns, the assault weapons ban was likely to be an issue that voters use in deciding who to support. Third, the vote on the ban was important to single-issue interest groups. This ban is a serious threat to pro-gun interests. Fourth, crime is one of most important issues to the electorate. Accordingly, social scientists should be interested in studying how the legislature deals with issues that are of concern to the public. Finally, the voting split (adopted 56-43) was close enough that there was sufficient variation for econometric tests to work (Kau \& Rubin, 1993, p. 157).

\section{EMPIRICAL MODEL}

The empirical model takes the following functional form:

$$
P_{i}=f\left(X_{c}, I_{c}, I_{s}\right)
$$

where $P_{i}$ is the probability that a senator from state $i$ votes yes on a particular issue, $X_{C}$ is a vector of constituent interests that have a stake in the outcome of the legislation, $I_{c}$ is the ideological preference of the senator's electoral constituency, and $I_{s}$ is the senator's ideology. ${ }^{\prime}$

The dependent variable in Equation (1) equals one if senator $i$ votes in favor of the assault weapons ban and zero if the senator votes against the ban. 
Our first constituency measure is the level of violent crime within a state. Voters are particularly concerned about the issue of violent crime. Three measures of such crimes are: the violent crime rate, the homicide rate, and the firearmrelated homicide rate. ${ }^{2}$ Each crime measure was entered separately in Equation (1). It seems reasonable to expect that the greater the rate of violent crime, the more likely citizens would be to desire a ban on assault weapons.

The second measure of constituent interests is the political strength of singleissue interest groups. The assault weapons ban is particularly threatening to progun interest groups. Politically, the National Rifle Association is the most powerful and influential pro-gun interest group. The organization tends to see banning any weapons as the first step toward eliminating all weapons (Kates, 1984). We used the percentage of the state's population who were members of the National Rifle Association as the measure of constituent opposition to the assault weapons ban. ${ }^{3}$ It was expected that the greater the constituency strength of the National Rifle Association, the less likely a senator would be to vote in favor of the assault weapons ban.

Over the 1976-1988 period, the CBS/New York Times Poll asked respondents their political party affiliation (Democrat, Independent, or Republican). Additionally, respondents were asked whether they would characterize their political views as liberal, moderate, or conservative. ${ }^{4}$ Responses were coded as follows: liberal +100 , moderate 0 , and conservative -100 . A mean was calculated for each political party (i.e., Democrats, Independents, and Republicans) within each state. The ideological preference of the electoral constituency of a Democratic (Republican) senator in state $i$ is the sum of the mean ideological score of Democrats (Republicans) plus the mean ideological score of Independents in state $i .^{5}$ Higher scores denote greater liberalism. It was expected that the greater the degree of liberalism of the senator's electoral constituency, the more likely the senator would be to vote in favor of the assault weapons ban.

Typically, social scientists have measured a senator's political philosophy by using interest-group ratings (Jackson \& Kingdon, 1992). We used the rating of the Americans for Democratic Action (ADA) to measure a senator's political liberalism. ${ }^{6}$ The ADA score is the percentage of a senator's votes which were in accordance with the liberal interest group's position on various issues. ${ }^{7} \mathrm{We}$ hypothesized that the more liberal the senator (i.e., the higher the ADA rating), the more likely he or she would be to vote in favor of the assault weapons ban.

\section{EMPIRICAL RESULTS}

Equation (1) is estimated using logit analysis because the dependent variable, the probability of voting in favor of the assault weapons ban, is binary. The empirical results appear in Table 1.8

Contrary to expectations, each crime measure is negative and statistically significant. This implies that the higher the crime rate within a state, the less likely the 
Table 1. Logit Estimates of Senate Votes Cast on the Assault Weapons Ban Dependent Variable $=$ Probability of Voting In Favor of the Ban

\begin{tabular}{lccc}
\hline \multicolumn{1}{c}{ Independent Variables } & $(7)$ & $(2)$ & $(3)$ \\
\hline Constant & 4.3371 & 4.3016 & 4.4497 \\
Violent Crime Rate & $(1.59)$ & $(1.68)^{*}$ & $(1.70)^{*}$ \\
Homicide Rate & -.0036 & - & - \\
& $(-2.33)^{* *}$ & -.2814 & -.4314 \\
Firearm-related Homicide Rate & - & $(-2.62)^{* * *}$ & $(-2.72)^{* * *}$ \\
NRA & - & -161.1036 \\
& & -149.8308 & $(-1.75)^{*}$ \\
Electoral Ideology & $(-1.65)^{*}$ & $(-1.72)^{*}$ & .0481 \\
& .0495 & .0505 & $(1.93)^{*}$ \\
Senator ADA Rating & $(1.99)^{* *}$ & $(2.06)^{* *}$ & .0351 \\
& .0368 & .0352 & $(1.85)^{*}$ \\
Likelihood Ratio Index & $(1.98)^{*}$ & $(1.93)^{*}$ & .56 \\
\hline
\end{tabular}

Note: T-statistics in parentheses (statistically significant at the ${ }^{*} .10$ level; ${ }^{* *} .05$ level; ***.01 level).

senator will be to vote in favor of the assault weapons ban. There are two possible reasons to explain this finding. First, citizens in states with high crime rates may oppose the assault weapons ban, believing it would take away their right to own guns for self-defense and family protcction. ${ }^{9}$ Sccond, while fcw peoplc are likcly to use an assault weapon for protection, those in states with high crime rates may perceive the proposal to ban assault weapons as a precursor to the elimination of all weapons from the hands of the law-abiding public.

As expected, the National Rifle Association variable is negative and statistically significant. The greater the percentage of a state's citizens who are members of the National Rifle Association, the less likely a senator was to vote in favor of the assault weapons ban.

The senator's ADA rating is positive and statistically significant. The more liberal a senator, the more likely she or he was to vote in favor of the assault weapons ban.

The ideology of the senator's electoral constituency is positive and statistically significant. The more liberal a senator's electoral constituency, the more likely a senator was to vote in favor of the assault weapons ban. This result suggests, as hypothesized, that by focusing on the entire legal constituency, as opposed to the electoral constituency, prior research may have underestimated the impact of constituency ideology on legislative voting.

It might be argued that the measure of a senator's political ideology is not "pure" since the ADA variable may incorporate elements of the electoral constituency ideology and a senator's personal characteristics (age, gender, marital status, 
Table 2. Logit Estimates of Senate Votes Cast on the Assault Weapons Ban (Senator Residual ADA Rating) Dependent Variable $=$ Probability of Voting In Favor of the Ban

\begin{tabular}{lccc}
\hline \multicolumn{1}{c}{ Independent Variables } & $(1)$ & $(2)$ & $(3)$ \\
\hline Constant & 7.1175 & 6.9796 & 7.1583 \\
& $(2.95)^{* * *}$ & $(3.33)^{* * *}$ & $(3.25)^{* * *}$ \\
Violent Crime Rate & -.0036 & - & - \\
& $(-2.31)^{* *}$ & & - \\
Homicide Rate & - & -.2808 & \\
& & $-2.63)^{* * *}$ & -.4354 \\
Firearm-related Homicide Rate & - & - & $(-2.75)^{* * *}$ \\
& -157.3076 & -145.8886 & $(-1.71)^{*}$ \\
NRA & $(-1.59)$ & $(-1.67)^{*}$ & .0832 \\
& .0867 & .0856 & $(4.84)^{* * * *}$ \\
Electoral Ideology & $(5.11)^{* * * *}$ & $(5.00)^{* * * *}$ & .0378 \\
& .0372 & .0368 & $(1.93)^{*}$ \\
Senator Residual ADA Rating & $(1.96)^{*}$ & $(1.96)^{*}$ & .56 \\
Likelihood Ratio Index & .51 & .53 & \\
\hline Note: ${ }^{*}$ T-statistics in parentheses (statistically significant at the *.10 level; **.05 level; ${ }^{* * *} .01$ level; ${ }^{* * * *} .001$ \\
$\quad$ level)
\end{tabular}

and religious affiliation). We followed the two-stage procedure suggested by Kau and Rubin (1979) to obtain a pure measure of a senator's political ideology. In the first stage, we regressed the senator's ADA rating on the ideology of the electoral constituency and the senator's personal characteristics. In the second stage, the residual from the first stage regression replaced the ADA variable and the model in Table 1 was reestimated.

The empirical results from using residual ADA ratings appear in Table 2. The results in Table 2 are virtually identical to those reported in Table 1 . Thus, the findings from Table 1 are robust. Our results suggest that the ideology of the senator's electoral constituency, as well as the characteristics of the legal constituency, single-issue interest groups, and the senator's political ideology affect senatorial voting.

\section{CONCLUSION}

Previous studies have used either demographic variables (e.g., income, education, etc.) or votes (e.g., the presidential vote in the state) to measure the ideology of the constituency. By using a self-reported measure, we measured constiluent ideology more accurately than previous research. Additionally, we conceptualized a legislator's constituency as being those voters most likely to vote for the legislator: members of the legislator's own political party plus inde- 
pendents. Our principle finding is that when constituent ideology is measured as discussed above, the ideology of the constituency becomes a more significant determinant of legislative voting than prior research suggests. ${ }^{10}$ Thus, it does seem that legislators respond to a large group of constituents, just not all of them.

Our results also indicate several productive paths for future research. First, we need to assess the impact of the electoral constituency on less salient votes than the assault weapons ban. Furthermore, as Kau and Rubin (1993) counsel, we need to more fully analyze the determinants of the ideology of the electoral constituency.

\section{NOTES}

1. It is a convention in the literature for constituent's ideological preferences $\left(I_{c}\right)$ to appear in Equation (1), even though it is a constituent interest. Consequently, all references to constituent interests in the text include constituency ideology.

2. These data are taken from the Uniform Crime Reports for the United States and the Sourcebook of Criminal Justice Statistics.

3. The number of members of the National Rifle Association per state was supplied by the organization itself. Another potential measure of organizational political strength, campaign contributions, suffer from endogeniety problems. While the contribution could "buy" a senator's vote, it is more likely that on ideologically oriented votes (such as the assault weapons ban) contributions go primarily to senators who are ideologically predisposed to support the group's position (Langbein, 1993). Population data were taken from the Statistical Abstract of the United States. Membership data for the primary pro-gun control organization (Handgun Control Incorporated) was unavailable.

4. The survey question was as follows: "How do you describe you views on most political matters? Generally, do you think of yourself as liberal, moderate, or conservative?" Using a longitudinal measure gives us a far larger number of respondents $(141,294)$ than in a typical exit poll (approximately 15,000). Hence, the measure should be more valid than could be obtained from a single survey. The data are reported in Erikson, Wright, and McGiver (1993, p. 40). The reliability between the 1976-1982 and 1983-1988 periods is an extremely high .976 (Erikson, Wright, \& McGiver, 1993, p. 32).

5. We also calculated a weighted score based upon the partisan group's contribution to the senator's electoral constituency. For example, if two-thirds of the total number of Democrats plus independents were Democrats, then the Democratic score was weighted twice as highly as the independent score. This measure correlates at .98 with the unweighted measure.

6. Jackson and Kingdon (1992) argue that interest group ratings overestimate the impact of ideology. Snyder (1992, pp. 332-333) indicates that rather than overestimating the impact of ideology, the S-shaped distribution of interest group rating scores actually causes them to underestimate the impact of ideology. Following Snyder (1992, p. 341) we also used the Poole and Rosenthal (1991) measure of ideology. For the latest year available (1989), their "dominant" dimension correlated with the 1989 ADA measure at -.95 . Thus, choice of an indicator makes little difference.

7. We have made two changes in the liberalism scores reported by the Americans for Democratic Action. Since the 1993 ADA ratings incorporate two votes similar to our dependent variable, we eliminated these votes from our version of the 1993 ADA ratings. Additionally, to avoid penalizing members for failure to vote, we recalculated the ADA scores as the percentage of times the senator voted in the direction supported by the ADA on the votes on which he or she 
voted. The votes were taken from 1993 and were supplied by the Americans for Democratic Action.

8. All the likelihood ratio index scores are above .50. This indicates that the models have a moderately high degree of explanatory power (on the use of the likelihood ratio index as a measure of goodness-of-fit for logit models, see Greene, 1993, pp. 651-653).

9. Since constituents might respond to change in the crime rate, as opposed to the absolute level of crime, we also reestimated the three equations in Table 1 with the percentage change in each of the crime measures for the two most recent years available. None of these measures were statistically significant.

10. We reestimated the equations shown in Table 1, replacing the liberalism of the electoral constituency with the mean liberalism of the legal constituency (i.e., the state). The mean liberalism of the legal constituency was never statistically significant. Furthermore, the other estimated coefficients remained qualitatively similar to those reported in Table 1.

\section{REFERENCES}

Bernstein, R.A. (1989). Elections, representation, and congressional voting behavior. Englewood Cliffs: Prentice Hall.

Congressional quarterly weekly reports. (1993, November 20). Washington, DC: U.S. Government Printing Office.

Erikson, R.S., G.C. Wright, \& J.P. McGiver. (1993). Statehouse democracy: Public opinion and policy in the united states. Cambridge, UK: Cambridge University Press.

Fenno, R.F. (1978). Home style: Representation in their districts. Boston, MA: Little, Brown.

Goff, B.L., \& K.B. Grier. (1993). On the (mis)measurement of legislator ideology and shirking. Public Choice, 76, 5-20.

Greene, W.H. (1993). Econometric analysis. 2nd edition. New York: Macmillan.

Jackson, J.E., \& J.W. Kingdon. (1992). Ideology, interest group scores, and legislative votes. American Joumal of Political Science, 36, 805-823.

Kates, D.B. (1984). Handgun banning in light of the prohibition experience. In D.B. Kates (Ed.), Firearms and violence (pp. 139-165). San Francisco, CA: Pacific Institute.

Kau, J.B., \& P.H. Rubin. (1979). Self-interest, ideology, and logrolling in congressional voting. Journal of Law and Economics, 22, 365-384.

Kau, J.B., \& P.H. Rubin. (1993). Ideology, voting, and shirking. Public Choice, 76, 151-172.

Krehbiel, K. (1993). Constituency characteristics and legislative preferences. Public Choice, 76, 21 37.

Langbein, L.I. (1993). PACs, lobbies and political conflict: The case of gun control. Public Choice, $77,551-572$.

Poole, K.T., \& H. Rosenthal. (1991). Patterns of congressional voting. American Journal of Political Science, 35, 228-278.

Snyder, J.M., Jr. (1992). Artificial extremism in interest group ratings. Legislative Studies Quarterly, 17, 319-345.

Sourcebook of criminal justice statistics. (1992). Washington, DC: U.S. Government Printing Office. Statistical abstract of the United States. (1992). Washington, DC: U.S. Government Printing Office. Uniform crime reports for the United States: 1992. (1992). Washington, DC: U.S. Government Printing Office. 